\section{BIOCHEMICAL VERSUS MORPHOLOGICAL EFFECTS OF HUMAN HEPATIC ALKALINE PHOSPHATASE IN A} NEONATE WITH HYPOPHOSPHATASIA. Manfred Weninger Robert A. Stinson*,Hanns Plenk, Florian Gotsauner,Peter Böck, * University of Alberta,Dept. of Patho, Children's hospital, Vienna ; * University of Alberta,Dept. of Pathology, Edmonton, Canada
Enzyme replacement therapy for a severely affected premato $2380 \mathrm{~g}, \mathrm{GA}: 36$ weeks) with hypophosphatasia was attempted boy (birthweigh purified purified human hepatic alkaline phosphatase(AP). Treatment started at age of two weeks and was repeated in weekly intervals until death ( 10 weeks).Samples of AP were diluted with $10 \mathrm{ml}$ of physiological saline and infused over a time span of 30 minutes via an umbilical arterial catheter.No toxic or allergic side effects were observed. Senum-AP increased from $3 \mathrm{mU} / \mathrm{ml}$ before treatment to a maximum level
of $195 \mathrm{mU} / \mathrm{ml}$ with a half -life time between 37 and 62 hours. Urinary excretion of phosphoethanolamine (PEA) decreased un 37 and 62 hours. Urinary excretion of to $5.5 \mu \mathrm{mol} / \mathrm{mg}$ creatinine (normal: $<0.4$ ). Calcium, phosphons, parathormone and 1-25 dihydroxyvitamin $D$ levels were within the normal range during therapy. Sequential radiographic studies showed no improvement of bone mineralization under therapy. Bone morphology was studied by light and electron microscopy before trentment and post mortem. In contrast to previous studies an unusually woven bundle bone structure was found with abrupt mineralization fronts without osteoblast-like cells. We conclude that this enzyme, substituted for the first time, altered PEA concentrations but failed to influe 1 ce the initial abnormal bone structure of this infint. GLUCOSE METABOLISM IN PRETERM AND TERM INFANTS OF
DIABETIC MOTIIERS IN THE FIRST HOURS OF LIFE. Rienk Baarsma, Tom Chapman, Wilma A van Asselt, DirkJan Reijngoud, Ruud Berger, Albert Okken. Div. Neonatology and Research Lab, Dept. of Pediatrics. University of Groningen, The Netherlands. There are almost no data on endogenous glucose production rate (EGPR) and glucose appearance rate (Ra gluc) in preterm infants of diabetic mothers (idm).

Therefore we studied 5 preterm and 8 term idm's within the first $24 \mathrm{~h}$ after birth (mean $8 \mathrm{~h}$ ). Ra gluc and EGPR were measured, prior to oral feeding, with the prime-dose constant-rate infusion technique, using 6,6-dideuteroglucose. To prevent hypoglycaemia all infants received a low dose glucose i.v. (mean $3.4 \mathrm{mg} / \mathrm{kg} / \mathrm{min}$ ) Results are shown in the table (mean, range).

\begin{tabular}{lcccc}
\hline Infant & $\begin{array}{c}\text { Gest.age } \\
(\text { wk })\end{array}$ & $\begin{array}{c}\text { Birthweight } \\
(\mathrm{g})\end{array}$ & $\begin{array}{c}\text { EGPR } \\
(\mathrm{mg} / \mathrm{kg} / \mathrm{min})\end{array}$ \\
\hline Preterm & 35.2 & 3170 & 1.0 & $\begin{array}{c}\text { Ra gluc } \\
\text { Term }\end{array}$ \\
$33-37$ & $1660-3990$ & $0-2.39$ & $3.16-5.44$ \\
& 38.9 & 3050 & 2.42 & 5.85 \\
& $38-40$ & $2170-4770$ & $0.56-4.78$ & $4.96-8.19$ \\
\hline
\end{tabular}

There are no significant differences in EGPR and Ra gluc between preterm and term idm's. In preterm idm's EGPR is lower than 92 OSTEOGENESIS IMPERFECTA: A LONGITUDINAL CLINICAL

U.Vetter, J. Ermisch, A. Wörsdörfer, W.M.Teller Department of Pediatrics $I$ and Surgery III University of Ulm, FRG.

Over a ten years period 60 children with osteogenesis imperfecta (0.J.) were studied.15 patients were classified as type I showing a clinically mild disease. 45 patients presenting with 0. I.at birth could be subdivided into group A(23) with "broad bone" type femurs and into group $B(22)$ with "thin bone"type femurs on neonatal radiographs. Group $A$ and to a lesser extent group $B$ showed significantly more skeletal abnormalities than type I. Starting from birth the annual incidence of fractures was high, however at a different level in group $A$ and $B$ and significantly declined after the age of 5 years. In contrast type I showed a peak of fractures at the age of 5 years. A considerable reduction in height and weight during the first 5 years was observed in group $A(-8 S D)$ and to a lesser extent in group $B(-4$ SD). Type I did no develop significant short stature. All patients showed a typical centrifugal body fat distribution. Cardiac malformations and kid ney stones were important extraskeletal manifestations of $0 . \mathrm{I}$. showing an incidence of los. IGFI levels were low, normal or slightly subnormal indicating normal growth hormone status.
95 SUCROSE SPACE (SSP) IN PRETERM INFANTS < $1500 \mathrm{~g}$ (PI): Bauer $K$, Versmold $H T$, Division of Neonatology, Dept. OB GYN, University of Munich, F.R.C.

GYN, University of Munich, F.R.G. However. the k!netlc model used may not apply to PI. We therefore studied SSp in $10 \mathrm{PI}(\mathrm{BW} 1.2 \pm 0.3 \mathrm{~kg} ; \mathrm{GA} 29 \pm 1.7 \mathrm{wks})$ A single IV dose of $0.6 \mathrm{mmol} / \mathrm{kg}$ sucrose was given on dayl. repeated on day 4 in 5 PI. Results, Conclustons: (1) SSp In PI was twice that in adults. Thls prolongs sucrose distributlon. (2) Only at 3 twice that in injection (pl) sucrose ellmination followed ist order klntics. Previous studles included the $2 \mathrm{~h}$ value (incomplete distribution) thus undes distribution) thus underestimating SSp by about $8 \%$ (3) Early distribution was studied in 2 cases only (ethical committee directlve). Sucrose disappearance curve was resolved into 3 exponential functions. $k_{3}(0.39 / \mathrm{min})$ and $k_{2}(0.04 / \mathrm{min})$ were similar in the $2 \mathrm{PI} . \mathrm{k}_{1}(n=15 ; 0.0011 \pm 0.0007 / \mathrm{min})$ was Increasing with increasing urinary output $(p<0,05)$ (4) SSp calculated from only 2 samples at 3 and 5 hpl was as accurate $(n=15+0.4 \pm 1.7 \%)$ as SSp calculated from 3 samples at 3,4 and $5 \mathrm{~h}$ pi, allowing to reduce the number of samples. This is cruclal if studying SSp in PI.

\begin{tabular}{|c|c|c|}
\hline$-x-p>01$ & Day $1(n=10)$ & Day $4(n=5$ \\
\hline $\begin{array}{l}\text { ge at injection(h) } \\
\text { ody weight(g) }\end{array}$ & $\begin{array}{r}6.8 \pm 5.2+ \\
1218 \pm 290\end{array}$ & 120 \\
\hline $\begin{array}{l}\text { crose space }(\mathrm{ml} / \mathrm{kg}) \\
\text { crose clearance (ml }\end{array}$ & $\begin{array}{l}463 \pm 61 \\
6.3 \pm 2.5\end{array}$ & 42 \\
\hline
\end{tabular}
93 METABOLIC AND ENZYMATIC INFLUENCE OF GLUCOSE SUPPLy

r. Henrichs, R. Benz ${ }^{\star}$ WUta Wittich ${ }^{\star 2}$,M. Kellner, W.M.Teller Center of pediatrics, $1_{\text {center of }}$ gynecology, 2 central unit of clin.chemistry, University of Ulm,D-7900 ULM FRG

$60 \%$ of the retained glucose is utilized by human placenta itself (Schneider et al.1981). In diabetic mothers, the macrosomia of the neonate and the placenta can be related to hyperglycemic conditions with functional fetal hyperinsulinism. We studied the influence of hypo- and hyperglycemic conditions in human placenta in vitro. METHODS: The brutto glucose utilization(bU'G) and the lactate production ( $\left(\mathrm{PP}^{\prime} \mathrm{L}\right)$, the lactate utilization( $\left.U^{\prime} L\right)$ and the glucose production ( $\left.P^{\prime} G\right)$ out of traced $L-(U-14 C)$ lactate were determined in explants of term placentae $(600 \mathrm{mg})$ incubated for $120 \mathrm{~min}$. RESULTS: 1 . With a glucose concentration from 100 to $500 \mathrm{mg} / \mathrm{dl}$, the bU' $G$ shows significant linear increase (from $3.27+1.9$ to $10.6+$ $1.5 \mu \mathrm{mol} / \mathrm{h} / \mathrm{g}$ placenta, $\overline{\mathrm{x}}+\mathrm{SD})$. Under hypoglycemic conditions, bP'L was low and U'L elevated related to euglycemia. Increasing hyperglycemia did not increase bP'L furthermore, but U'L. Phosphoenolpyruvate carboxykinase (PEP-CK), a gluconeogenic key enzyme, was reduced to $40 \%$ by $400 \mathrm{vs}$. $100 \mathrm{mg} / \mathrm{dl}$ glucose concentrations.CONCLUSION: Glucose supply induced $\mathrm{CH}$ metabolism and lowered PEP-CK activity.

Supported by DEG, He $1107 / 2$
96 RED BLOOD CELL TOCOPHEROL STATUS IN PREMATURE INFANTS $\frac{\text { Frank J. Kelly }}{\text { (spon. by C. Normand), University of Southampton, }}$, Departments of Human Nutrition and CHild Health* Southampton.

Plasma and red blood cell (RBC) tocopherol isomer concentrations were determined serially in 35 promature infants (26-34w gestation) from birth to 6 weeks of age. Blood samples $(0.5 \mathrm{ml})$ were collected shortly following birth and thence twice
we weekly in conjunction with samples obtained for clinical management. Plasma and RBC tocopherol isomers were separated using high pressure liquid chromatography. Following birth, plasma total tocopherol concentration was $0.07+0.05 \mathrm{mg} / \mathrm{dl}$. This concentration increased to $0.35+0.24 \mathrm{mg} / \mathrm{d} 1$ by week 6 (range 0.08-0.56). The normal adult plasma tocopherol range in Southampton is $0.63-1.24 \mathrm{mg} / \mathrm{dl}$. RBC total tocopherol concentration was $0.15 \pm 0.11$ at $24 \mathrm{~h}$. This concentration increased to 0.22 $\pm 0.18 \mathrm{mg} / \mathrm{dl}$ (range $0.14-0.46 \mathrm{mg} / \mathrm{dl}$ ) by week 6 of the study. Normal adult range of RBC, tocopherol was determined to be $0.20-0.39 \mathrm{mg} / \mathrm{dl}$. In the majority of the infants over $90 \%$ of the vitamin $\mathrm{E}$ present in plasma and $\mathrm{RBC}$ was $\alpha$-tocopherol. It is concluded from these results that although preterm infants had abnormally low plasma tocopherol concentrations at birth and did not achieve normal levels within 6 weeks, they may not in fact be vitamin $E$ deficient on the basis of their RBC tocopherol concentrations. 